\title{
Ten-year mortality in a sample of an adult population in relation to air pollution
}

\author{
MICHAŁ KRZYŻANOWSKI AND BOGDAN WOJTYNIAK \\ From the Department of Medical Statistics, National Institute of Hygiene, Warsaw, Poland
}

SUMmaRY The 10-year mortality in a sample of adult inhabitants of Cracow, Poland, was analysed according to the levels of air pollution in the area of residence. Smoking habit and several social and occupational factors were considered in the analysis, which was carried out with the use of a multivariate method for categorical variables. Among men the main effect of air pollution was marginally significant, but there was a significant interaction between air pollution and smoking. Among women no such relation could be detected. Also, the association between female mortality and smoking was not significant. From other factors considered in the analysis, only exposure at work to dust, high humidity, and variable temperature was related to mortality in both men and women. In addition among women higher mortality was related to a lower level of education.

The effects of air pollution on health in an urban environment continue to be the subject of discussion. ${ }^{2}$ Various studies indicate that the possible effect of air pollution on mortality is relatively small and may be influenced by several confounding factors, such as smoking habit and occupational or socioeconomic conditions that also generally affect mortality. ${ }^{3-5}$ One way to assess the effects of air pollution on health, taking into account these confounding factors, is a longitudinal epidemiological study of populations exposed to various levels of air pollution. This is laborious to organise and conduct but affords relatively exact data on individuals who may be followed up for many years. In this paper we present the mortality after 10 years in a random sample of residents of the higher and lower polluted areas of Cracow.

\section{Population and methods}

In 1968 a sample of the adult population of Cracow, a city inhabited at that time by 555000 people, was examined to estimate the prevalence of chronic non-specific respiratory diseases. ${ }^{6}$ The sample was selected at random from permanent residents of Cracow aged from 19 to 70 years by using the register of dwellings as a sampling frame. Standard interviews were obtained from 4355 subjects who formed $94 \%$ of the random sample. The interviews included questions on respiratory symptoms, smoking habits, education, place of birth, housing conditions, type and place of work, and possible exposure to occupational hazards,

Independently of the population study, during 1968-73, measures of ambient air pollution were collected by 20 samplers placed at regular intervals of about $2.5 \mathrm{~km}$ in the town area. The devices for continuous measurements were similar to those designed by Warren Spring Laboratory in Britain. The aspirated air passed through a Whatman No 1 filler clump, and bubbled through a fluid to absorb sulphur compounds. The paper filters and bubblers were collected daily except on Sundays and holidays. Concentrations of suspended particulate matter of diameter less than $10 \mu \mathrm{m}$ were determined by an EEL smoke stain reflectometer and concentrations of $\mathrm{SO}_{2}$ by a Specol electrophotocolorimeter. With this data we established that in the five-year period the central part of the city had the highest atmospheric pollution; the mean daily concentration of particulate matter was $180 \mu \mathrm{g} / \mathrm{m}^{3}$ and of $\mathrm{SO}_{2}$ $114 \mu \mathrm{g} / \mathrm{m}^{3}$. In the remaining areas the daily mean for particulate matter was $109 \mu \mathrm{g} / \mathrm{m}^{3}$ and for $\mathrm{SO}_{2}$ $53 \mu \mathrm{g} / \mathrm{m}^{3}$, and only occasionally did air pollution in these areas exceed those in the centre of the city (figs 1 and 2). There were 658 people living in the centre (15\% of the study sample), and we regarded these people as a group exposed to high atmospheric pollution.

In 1978,10 years after the primary study, we returned to the study population to identify who were alive, who were dead, and if dead what had caused their death. 


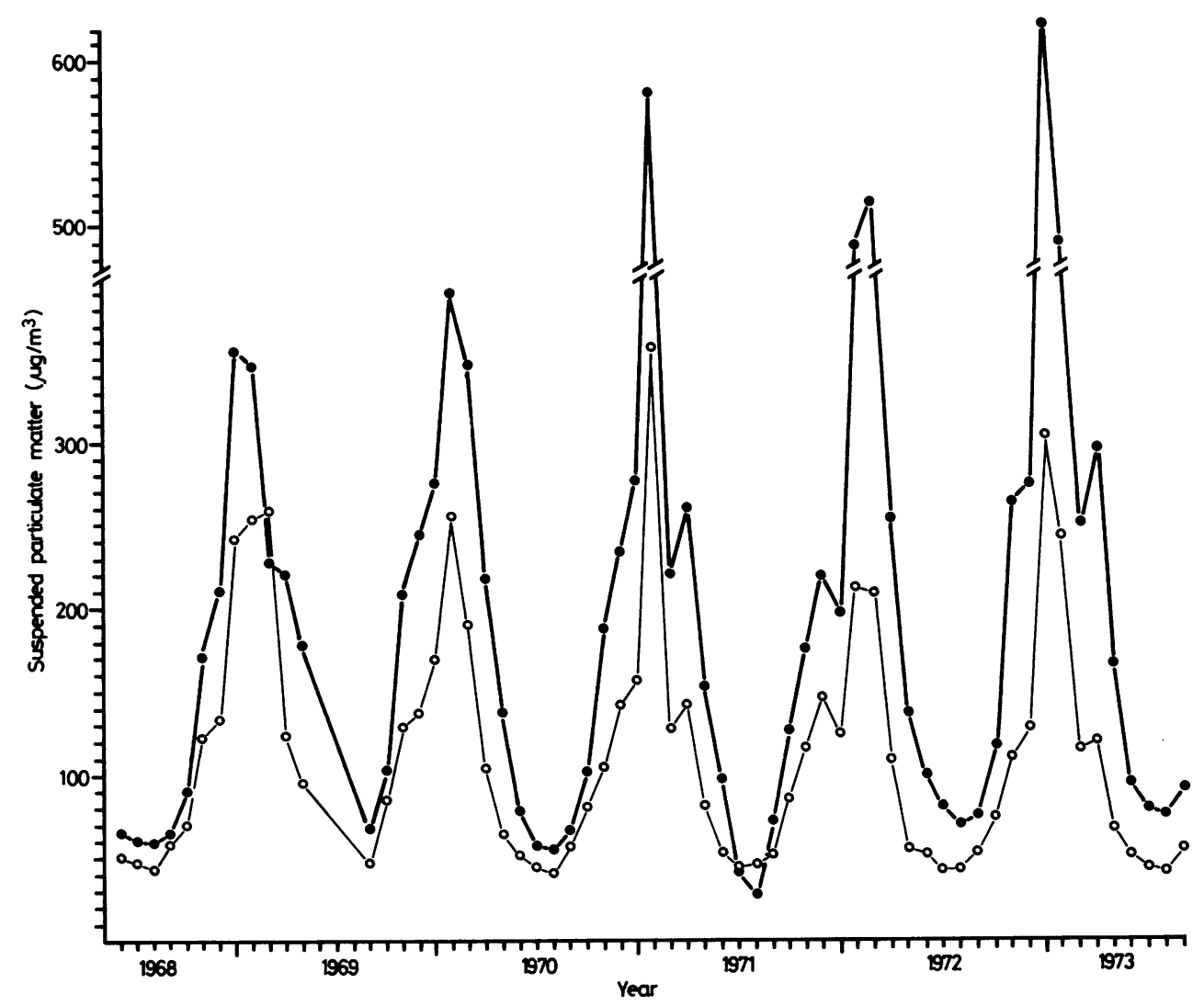

Fig 1 Monthly averages of air pollution with suspended particulate matter in the centre ( - ) and in the remaining area of Cracow (_ ) during 1968-73.

\section{METHOD OF ANALYSIS}

The method of analysis has been described in detail by Freeman, Wojtyniak, and Krzyżanowski (submitted for publication) and is based on that of Grizzle et al. ${ }^{7}$ Linear models (similar to those in the analysis of variance) were constructed in which age-adjusted mortality rates were explained by various social and environmental factors. The significance of the effects of particular factors was tested by the statistic $Q$, which has a $\chi^{2}$ distribution with degrees of freedom equal to the number of parameters tested simultaneously. Coefficient $\hat{b}$ estimated in the model can be interpreted as the differential effect of the respective category of given factor measured relative to the average mortality level $\hat{\mathbf{m}}$.

If the age-standardised mortality rates were computed for every combination of categories of each possible factor the frequency of these combinations would be small; this limits the number of factors that can be analysed simultaneously.
Consequently, we did not estimate one general model including all factors, but tested several models each containing one, two, or three confounding factors in addition to air pollution and smoking, which were the factors in which we were most interested. Table 1 shows the list of factors included in the analysis and the groupings used.

We calculated the probability of death in the 10-year period due to all causes except accidents using the formula:

$$
q=\frac{d}{n-w-0.5 a}
$$

where $q=$ probability of death

$\mathrm{d}=$ number of deaths in 10 years excluding accidents

$\mathrm{n}=$ number of persons in the study at 1968

$\mathbf{w}=$ number of persons lost to follow-up at 1978

$a=$ number of deaths due to accidents in the 10 years 


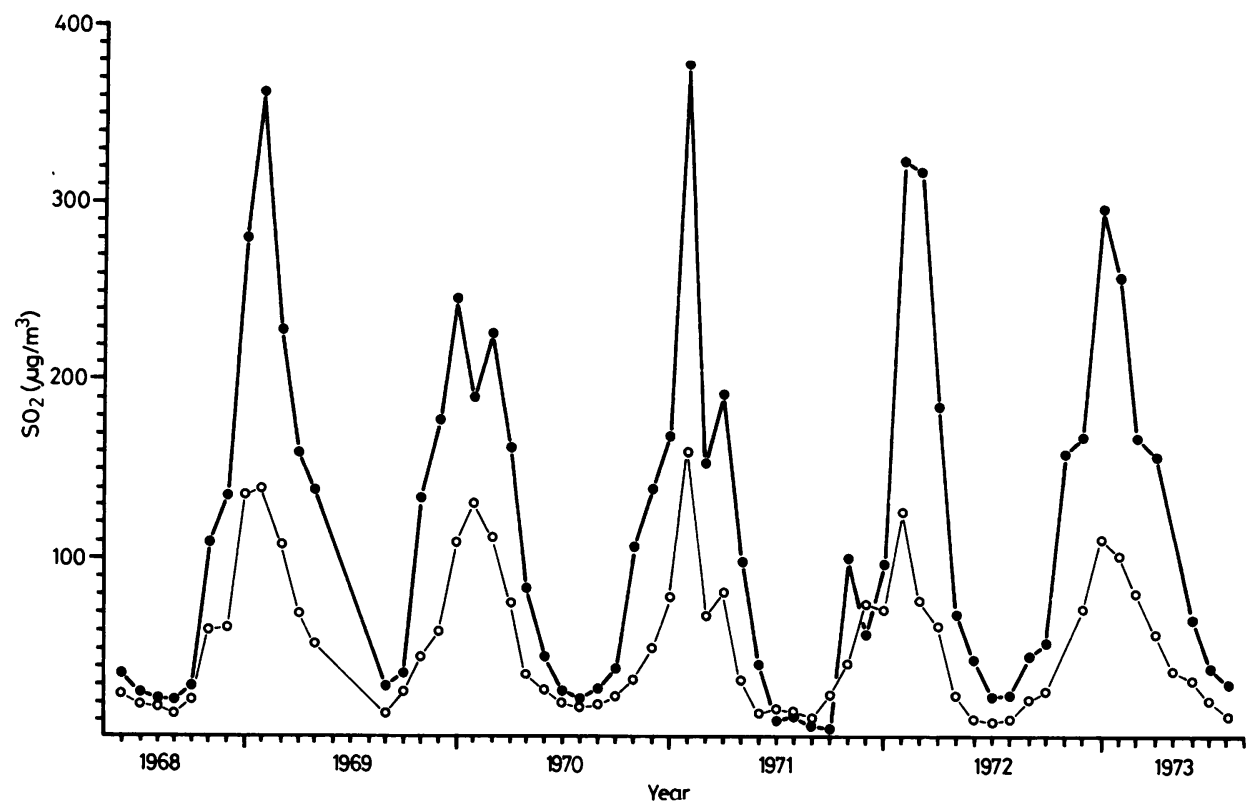

Fig 2 Monthly averages of air pollution with sulphur dioxide $\left(\mathrm{SO}_{2}\right)$ in the centre (-) and in the remaining area of Cracow (- ) during 1968-73.

The proportion of deaths due to accidents was $10.9 \%$ for men and $3.2 \%$ for women; the proportion of the study population lost to follow-up was $1.4 \%$ for men and $1.3 \%$ for women.

We then calculated age-adjusted mortality rates using indirect standardisation with the total examined group as standard. ${ }^{8}$

\section{Results}

We were able to identify 4296 individuals ( $98.6 \%$ of the study population, of whom $308(7 \cdot 2 \%)$ had died in the 10-year period (table 2 ). Only $59(1.4 \%)$ of the original population had been lost to follow-up.

The basic linear model of age-standardised mortality on air pollution and smoking habit in men confirmed the highly significant effect of smoking (table 3). The exposure to higher levels of air pollution increased mortality, but this effect was most clearly seen in smokers as the interaction term between air pollution and smoking significantly improved the fit of the model.

We extended this model to consider the influence of place of work and type of work at the time of the interview. The resulting model (table 4) confirmed the influence of increased air pollution on mortality in smokers and showed that non-industrial places of work had a raised risk of mortality, but there was little difference between manual and non-manual type of work. There was an important interaction between raised air pollution and non-industrial place of work.

Exposures to occupational hazards were also considered in the analysis (table 4), and while the effect of chemicals or irritating gas did not increase mortality, the various other hazards (dust, temperature, or humidity) did have an effect.

When place of birth was included in the analysis the interaction effect of air pollution and smoking diminished, and the model indicated that men born in Cracow and in rural areas are more susceptible than immigrants born in towns outside Cracow to the high air pollution.

Dwelling conditions did not affect mortality in men, nor did level of education.

Since these confounding factors were themselves interrelated we took into the basic model of air pollution and smoking two or three other factors at a time which had been shown to have some effect-place of work, exposure to various occupational hazards, and place of birth. On the basis of this analysis we estimated a final model that included only three factors (table 5). This showed that the effects of smoking and various occupational exposures as well as the effect of air pollution in smokers are significant. The main effect of air pollution itself was just on the border of statistical significance. 
Table 1 Categories used to classify the study population

\begin{tabular}{|c|c|c|c|}
\hline $\begin{array}{l}\text { Place of work } \\
\text { Type of work } \\
\text { Occupational } \\
\text { hazards }\end{array}$ & $\begin{array}{l}\text { High } \\
\text { Low } \\
\text { Male smokers } \\
\text { Female smokers } \\
\text { Industrial } \\
\text { Non-industrial } \\
\text { Manual } \\
\text { Non-manual } \\
\text { Chemical } \\
\text { Various } \\
\\
\text { Cracow } \\
\text { Other town } \\
\text { Rural } \\
\text { Crowded } \\
\text { Less crowded } \\
\text { University } \\
\text { High } \\
\text { Elementary }\end{array}$ & $\begin{array}{l}A_{1} \\
A_{0} \\
S_{1} \\
S_{0} \\
\\
S_{1} \\
S_{0} \\
W_{1} \\
W_{0} \\
M_{1} \\
M_{0} \\
C_{1} \\
C_{1} \\
V_{1} \\
\\
V_{0} \\
B_{0} \\
B_{1} \\
B_{1} \\
C_{1} \\
C_{0} \\
E_{2} \\
E_{1} \\
E_{0}\end{array}$ & $\begin{array}{l}\text { Residents in } 1968 \text { of the defined central area } \\
\text { Resident in } 1968 \text { elsewhere in Cracow } \\
\text { Current smokers who had smoked at least one cigarette a day in } 1968 \\
\text { Non-smokers (never smoked) and ex-smokers-that is, those who had either never smoked } \\
\text { regularly or who had given up smoking for at least one month before interview } \\
\text { Smokers (current smokers and ex-smokers) } \\
\text { Never smoked } \\
\text { Place of work-industrial } \\
\text { Place of work-commercial, administrative, or other } \\
\text { Manual workers } \\
\text { Non-manual workers } \\
\text { Exposed at work to chemicals or irritating gases for at least five years } \\
\text { Not exposed } \\
\text { Exposed at work to various hazards, such as dusts, variable temperature, or high } \\
\text { humidity, to one or more, each for at least five years } \\
\text { Not exposed to any of above } \\
\text { Born in Cracow } \\
\text { Born in another town } \\
\text { Born in a rural area } \\
\text { Living area less than } 10 \mathrm{~m}^{2} \text { per inmate } \\
\text { Living area more than } 10 \mathrm{~m}^{2} \text { per inmate } \\
\text { Education level over } 15 \mathrm{years}^{2} \text { of school } \\
11-14 \text { years of school } \\
\text { Education level under } 11 \text { years of school }\end{array}$ \\
\hline
\end{tabular}

Table 2 Number of men and women in each category in 1968, number died 1968-78, and age-standardised mortality

\begin{tabular}{|c|c|c|c|c|c|c|}
\hline \multirow[b]{2}{*}{ Category } & \multicolumn{3}{|l|}{ Men } & \multicolumn{3}{|l|}{ Women } \\
\hline & No of cases & No dead & $A S M^{*}$ & No of cases & No dead & $A S M$ \\
\hline $\begin{array}{l}A_{1} \\
A_{0} \\
S_{1} \\
S_{0} \\
W_{1} \\
W_{0} \\
M_{1} \\
M_{0} \\
C_{1} \\
C_{1} \\
V_{1} \\
V_{0} \\
B_{0} \\
B_{T} \\
B_{2} \\
C_{2} \\
C_{0} \\
E_{2} \\
E_{1} \\
E_{0}\end{array}$ & $\begin{array}{r}255 \\
1645 \\
1258 \\
642 \\
825 \\
999 \\
1066 \\
758 \\
439 \\
1461 \\
769 \\
1131 \\
707 \\
394 \\
799 \\
969 \\
931 \\
288 \\
766 \\
846\end{array}$ & $\begin{array}{r}42 \\
141 \\
133 \\
50 \\
71 \\
110 \\
123 \\
58 \\
42 \\
141 \\
106 \\
77 \\
69 \\
40 \\
74 \\
79 \\
104 \\
21 \\
61 \\
101\end{array}$ & $\begin{array}{r}122.0 \\
82.8 \\
112.4 \\
61 \cdot 8 \\
86.9 \\
96.6 \\
100 \cdot 2 \\
81 \cdot 0 \\
91.6 \\
91 \cdot 6 \\
109.9 \\
73.8 \\
110 \cdot 1 \\
78 \cdot 3 \\
87.1 \\
91.3 \\
92.0 \\
82.9 \\
88.0 \\
96.2\end{array}$ & $\begin{array}{r}389 \\
2007 \\
711 \\
1685 \\
767 \\
1263 \\
1039 \\
991 \\
223 \\
2173 \\
503 \\
1893 \\
875 \\
579 \\
942 \\
1148 \\
1248 \\
196 \\
940 \\
1260\end{array}$ & $\begin{array}{r}21 \\
104 \\
40 \\
85 \\
29 \\
61 \\
61 \\
29 \\
10 \\
115 \\
40 \\
85 \\
39 \\
33 \\
53 \\
53 \\
72 \\
2 \\
31 \\
92\end{array}$ & $\begin{array}{l}35 \cdot 4 \\
52 \cdot 1 \\
60 \cdot 3 \\
44 \cdot 3 \\
51 \cdot 5 \\
47 \cdot 0 \\
48 \cdot 4 \\
36 \cdot 9 \\
48 \cdot 8 \\
48 \cdot 3 \\
64 \cdot 4 \\
43 \cdot 2 \\
46 \cdot 8 \\
44 \cdot 0 \\
52 \cdot 7 \\
54 \cdot 5 \\
44 \cdot 7 \\
14 \cdot 5 \\
40 \cdot 3 \\
55 \cdot 0\end{array}$ \\
\hline $\begin{array}{l}\text { Total No of cases } \\
\text { analysed } \\
\text { Cases lost to } \\
\text { follow-up }\end{array}$ & $\begin{array}{r}1900 \\
25\end{array}$ & $\begin{array}{l}183 \\
-\end{array}$ & $\begin{array}{l}91 \cdot 7 \\
-\end{array}$ & $\begin{array}{r}2396 \\
34\end{array}$ & $\begin{array}{l}125 \\
-\end{array}$ & $\begin{array}{l}48 \cdot 3 \\
-\end{array}$ \\
\hline
\end{tabular}

*ASM = Age-standardised mortality per 1000 population. .

Table 3 Analysis of variation of age-standardised mortality rates in men: basic model

\begin{tabular}{|c|c|c|c|c|}
\hline \multirow{2}{*}{$\begin{array}{l}\text { Source of } \\
\text { variation }\end{array}$} & \multirow[b]{2}{*}{ Hypothesis } & \multirow[b]{2}{*}{ p-value } & \multicolumn{2}{|c|}{ Estimates* } \\
\hline & & & 6 & $S E_{6}$ \\
\hline $\begin{array}{l}\text { Air pollution } \\
\text { Smoking } \\
\text { Air pollution } \\
\text { in smokers } \\
\text { Model } \\
\text { Goodness of } f\end{array}$ & $\begin{array}{l}A_{1}=0 \\
S_{1}=0 \\
A_{1} \times S_{1}=0 \\
A_{1}=S_{1}=A_{1} \times S_{1} \\
\text { perfect - saturate }\end{array}$ & $\begin{array}{rl} & 0.077 \\
& 0.000 \\
& \\
& 0.032 \\
=0 & 0.000 \\
\text { ed model } & \end{array}$ & $\begin{array}{l}14 \cdot 92 \\
37 \cdot 20 \\
18 \cdot 07 \\
-\end{array}$ & $\begin{array}{l}8 \cdot 42 \\
8 \cdot 42 \\
8 \cdot 42 \\
-\end{array}$ \\
\hline
\end{tabular}

Estimated overall mean $\hat{m}=96 \cdot 95, \mathrm{SE}_{\mathrm{m}}=8 \cdot 42$; deaths per 1000 population.
In a similar analysis for women the definition of the smoking categories differed; for women ex-smokers were joined with the current smokers to form a group of "ever smoked" in comparison to "never smoked." In women the basic linear model comprising two factors, air pollution and smoking, was not significant, although it fitted the data satisfactorily (table 6). Smoking had no effect and air pollution was on the border of significance, $p=0.053$, but the higher mortality was in the less polluted areas. This strange effect became even more pronounced when 
Table 4 Results of fitting various models to age-standardised mortality rates in men

\begin{tabular}{|c|c|c|c|c|}
\hline Model* & Effects & $6+$ & $p \ddagger$ & $\begin{array}{l}\text { Goodness } \\
\text { of fit }\end{array}$ \\
\hline $\begin{array}{l}\text { Ma } \\
\text { (place and type } \\
\text { of work) }\end{array}$ & $\begin{array}{l}A_{1} \\
S_{1} \\
A_{1} \times S_{1} \\
W_{0} \\
A_{1}{ }^{x_{1}} \mathbf{W}_{0} \\
M_{1}\end{array}$ & $\begin{array}{r}10.79 \\
39.98 \\
21.95 \\
15.91 \\
13.15 \\
7.75\end{array}$ & $\begin{array}{l}0.151 \\
0.000 \\
0.003 \\
0.020 \\
0.061 \\
0.187\end{array}$ & $\begin{array}{l}Q_{e}=4.79 \\
d f=9 \\
p=0.852\end{array}$ \\
\hline $\begin{array}{l}\text { Mb } \\
\text { (occupational } \\
\text { exposures) }\end{array}$ & $\begin{array}{l}A_{1} \\
S_{1} \\
A_{1} x S_{1} \\
V_{1} \\
C_{1} H_{1}\end{array}$ & $\begin{array}{r}10.90 \\
29.25 \\
13.54 \\
17.02 \\
-\quad 7.45\end{array}$ & $\begin{array}{l}0.147 \\
0.000 \\
0.071 \\
0.008 \\
0.291\end{array}$ & $\begin{array}{l}Q_{e}=12.62 \\
d f=10 \\
p=0.245\end{array}$ \\
\hline $\begin{array}{l}\text { Mc } \\
\text { (place of } \\
\text { birth) }\end{array}$ & $\begin{array}{l}\mathbf{A}_{\mathbf{1}} \\
\mathbf{S}_{\mathbf{1}} \\
\mathbf{A}_{1} \times \mathbf{S}_{\mathbf{1}} \\
\mathbf{B}_{\mathbf{C}} \\
\mathbf{B}_{\mathbf{T}} \\
\mathbf{A}_{\mathbf{1}} \times \mathbf{B}_{\mathbf{C}} \\
\mathbf{A}_{\mathbf{1}} \times \mathbf{B}_{\mathbf{r}}\end{array}$ & $\begin{array}{r}8.48 \\
32.60 \\
13.33 \\
20.16 \\
-29.57 \\
13.66 \\
-33.15\end{array}$ & $\begin{array}{l}0.278 \\
0.000 \\
0.094 \\
0.073 \\
0.007 \\
0.245 \\
0.003\end{array}$ & $\begin{array}{l}Q_{e}=3.73 \\
\text { df }=4 \\
p=0.444\end{array}$ \\
\hline
\end{tabular}

*Confounding factors in parentheses.

tDeaths per 1000 population.

$\ddagger$ Probability of $Q_{c}$ for the given effect $\left(H_{0}: b=0\right)$.

Table 5 Analysis of variation of age-standardised mortality rates in men: final model

\begin{tabular}{|c|c|c|c|c|}
\hline \multirow{2}{*}{$\begin{array}{l}\text { Source of } \\
\text { variation }\end{array}$} & \multirow[b]{2}{*}{ Hypothesis } & \multirow[b]{2}{*}{ p-value } & \multicolumn{2}{|c|}{ Estimates * } \\
\hline & & & 6 & $S E b$ \\
\hline $\begin{array}{l}\text { Air pollution } \\
\text { Smoking habit } \\
\text { Air pollution }\end{array}$ & $\begin{array}{l}\mathbf{A}_{1}=0 \\
\mathbf{S}_{1}=0\end{array}$ & $\begin{array}{l}0.051 \\
0.000\end{array}$ & $\begin{array}{l}15 \cdot 79 \\
34.96\end{array}$ & $\begin{array}{l}8.09 \\
8.31\end{array}$ \\
\hline $\begin{array}{l}\text { in smokers } \\
\text { Various } \\
\text { occupational }\end{array}$ & $A_{1} \bar{x} S_{1}=0$ & 0.029 & 17.74 & $8 \cdot 12$ \\
\hline $\begin{array}{l}\text { exposures } \\
\text { Model }\end{array}$ & $\begin{array}{l}V_{1}=0 \\
A_{1}=S_{1}= \\
A_{1} \times S_{1}= \\
=V_{1}=0\end{array}$ & $\begin{array}{l}0.023 \\
0.000\end{array}$ & $\begin{array}{l}13.94 \\
-\end{array}$ & $\begin{array}{l}6 \cdot 13 \\
-\end{array}$ \\
\hline $\begin{array}{l}\text { Goodness of } \\
\text { fit }\end{array}$ & & 0.785 & - & - \\
\hline
\end{tabular}

"Estimated overall mean $\mathrm{m}=98 \cdot 17, \mathrm{SE}_{\mathrm{m}}=8 \cdot 16$; deaths per 1000 population.

Table 6 Analysis of variation of age-standardised mortality rates in women: basic model

\begin{tabular}{lllll}
\hline & & & \multicolumn{2}{l}{ Estimates* } \\
\cline { 3 - 5 } $\begin{array}{l}\text { Source of } \\
\text { variation }\end{array}$ & Hypothesis & p-value & $b$ & SEb \\
\hline Air pollution & $A_{1}=0$ & 0.053 & -8.49 & 4.38 \\
Smoking habit & $\mathrm{S}_{1}=0$ & 0.168 & 6.59 & 4.79 \\
$\begin{array}{l}\text { Model } \\
\text { Goodness of }\end{array}$ & $\mathrm{A}_{1}=\mathrm{S}_{1}=0$ & 0.079 & - & - \\
$\quad$ & & 0.152 & - & - \\
\hline fit & & 0.152 & - & - \\
\hline
\end{tabular}

Estimated overall mean $\hat{m}=46 \cdot 38, \mathrm{SE}_{\mathrm{m}}=4 \cdot 99$; deaths per 1000 population.

the occupational exposures were considered; the mortality of women exposed to various hazards (dust, temperature, and humidity) was bisher than those not exposed, whereas exposure to chemicals or gases reduced mortality (table 7 ).

Introducing education into the model had a significant effect in the expected direction-that
Table 7 Results of fitting various models to age-standardised mortality rates in women

\begin{tabular}{|c|c|c|c|c|}
\hline Model* & Effects & $\boldsymbol{b}^{+}$ & $p \ddagger$ & $\begin{array}{l}\text { Goodness } \\
\text { of fit }\end{array}$ \\
\hline $\begin{array}{l}\text { Wa } \\
\text { (occupational } \\
\text { exposures) }\end{array}$ & $\begin{array}{l}\mathbf{A}_{\mathbf{1}} \\
\mathrm{S}_{1} \\
\mathbf{V}_{1} \\
\mathbf{C H}_{1}\end{array}$ & $\begin{array}{r}-10.66 \\
0.69 \\
16.99 \\
-19.59\end{array}$ & $\begin{array}{l}0.006 \\
0.852 \\
0.000 \\
0.000\end{array}$ & $\begin{array}{l}Q_{e}=14.64 \\
d f=9 \\
p=0.101\end{array}$ \\
\hline $\begin{array}{l}\text { Wb } \\
\text { (education) }\end{array}$ & $\begin{array}{l}A_{1} \\
S_{1} \\
E_{0} \\
E_{1}\end{array}$ & $\begin{array}{r}5 \cdot 22 \\
4 \cdot 68 \\
24 \cdot 11 \\
8 \cdot 77\end{array}$ & $\begin{array}{l}0.204 \\
0.185 \\
0.000 \\
0.077\end{array}$ & $\begin{array}{l}Q_{e}=7.80 \\
d f=7 \\
p=0.350\end{array}$ \\
\hline $\begin{array}{l}\text { Wc } \\
\text { (place of birth) }\end{array}$ & $\begin{array}{l}\mathbf{A}_{1} \\
S_{\mathbf{1}} \\
\mathbf{B}_{\mathbf{C}} \\
\mathbf{B}_{\mathbf{T}} \\
\mathbf{A}_{\mathbf{1}} \mathbf{B B}_{\mathbf{C}} \\
\mathbf{A}_{\mathbf{1}} \mathbf{x} \mathbf{B}_{\mathbf{r}}\end{array}$ & $\begin{array}{r}-6.32 \\
4.44 \\
7.68 \\
-10 \cdot 12 \\
14.74 \\
-10.98\end{array}$ & $\begin{array}{l}0.181 \\
0.315 \\
0.311 \\
0.086 \\
0.051 \\
0.063\end{array}$ & $\begin{array}{l}Q_{e}=5.65 \\
d f=5 \\
p=0.342\end{array}$ \\
\hline
\end{tabular}

*Confounding factors in parenthesis.

tDeaths per 1000 population.

$\mp$ Probability of $Q_{c}$ for the given effect $\left(H_{0}: b=0\right)$.

Table 8 Analysis of variation of age-standardised mortality rates in women: final model

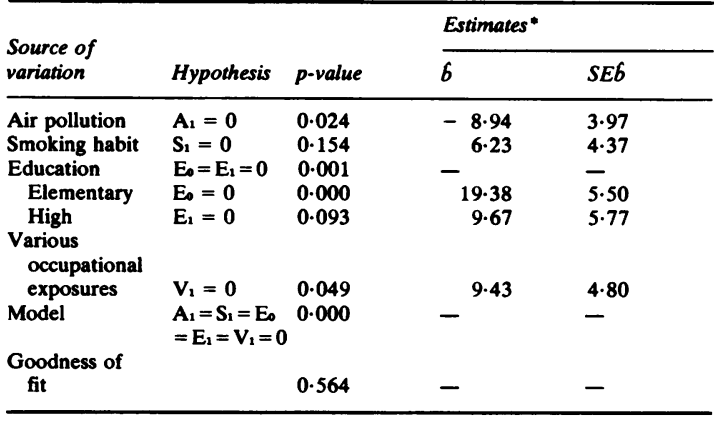

*Estimated overall mean $\mathrm{m}=33 \cdot 57, \mathrm{SE}_{\hat{\mathrm{m}}}=5 \cdot 83$; deaths per 1000 population.

women with higher education have lower mortality. Of the other confounding factors, only the place of birth modifies to some extent the relation between air pollution and mortality in that natives of Cracow have a somewhat increased mortality in the polluted central area. The opposite effect is seen in migrants born in other towns.

It was not possible to proceed to a model for women that considered simultaneously the two main factors and three other confounding factors, as the number of deaths was too few to construct the many cells of the contingency table. We therefore constructed two separate models with two additional confounding factors in each-educational level with one type of occupational exposure at a time.

In the model considering air pollution, smoking, education, and exposure to chemicals or irritating gases no regular pattern of mortality rates could be detected, and models with first-order interactions were not fitted. When the various hazards were substituted for the chemical hazards, more regular 
patterns could be observed (table 8). There was increased mortality in women living in the areas of lower air pollution, in those with less education, and in those exposed to various hazards,

\section{Discussion}

In most studies of long-term effects of air pollution on mortality the authors correlated the mortality rates in different territories with the characteristics of air pollution in these areas. ${ }^{9-11}$ The main problems in such studies are connected with a measurement of confounding factors, and the only values it is possible to use in the analysis are usually crude characteristics of the area. In a prospective epidemiological study information on every individual is available, but the method of data collection limits the number of people who can be examined, which diminishes the validity of observed death rates. Relatively small numbers of deaths in the follow-up period and qualitative data on confounding factors also restrict the number of factors that can be considered simultaneously in the analysis.

Nevertheless, the data used in our study enabled us to detect some associations that are difficult to find in an analysis based on aggregated data. One is the interaction effect of air pollution and-cigarette smoking observed in men, indicating that men who smoke have a higher susceptibility to pollutants. This finding differs from the conclusion of Morris et $\mathbf{l}^{12}$ who could not show more than an additive effect of air pollution and smoking on 13 years' mortality.

We checked if the interaction observed in our data did not result from differences in the habit of residents of the more and less polluted areas who smoked. The distributions of duration of smoking and of the amount of cigarettes smoked daily, however, were similar in both groups.

For women the results of our study are similar to the observations of Morris ${ }^{12}$ : in both studies there was no excess mortality in women residing in more polluted areas. Opposite results have been reported by Brozzo et al, ${ }^{13}$ who had found an association between female mortality and the level of air pollution. The strength of that correlation, however, had been 2.5 times smaller than that observed for men.

The lack of interaction between smoking and air pollution in women may be partly explained by the much smaller effect of smoking on mortality in women than in men observed in our study as well as in some previous ones. ${ }^{14}$ This weak influence of the habit may be areason why air pollution has no effect even in a smoking group.

The relatively small number of deaths in the group followed up for 10 years severely restricted the possibility of cause-specific analysis. For men, however, we could detect that the greatest excess of mortality in the residents of the highly polluted area was due to deaths caused by malignant neoplasms of the respiratory system, arteriosclerosis, pulmonary heart disease, and chronic bronchitis, emphysema, and asthma. This only partly supports the findings of Brozzo et al.$^{13}$ The higher overall mortality in women residing in areas with lower air pollution was due to diseases of the circulatory system.

We could not identify which of the two types of air pollution we considered (suspended particulates or $\mathrm{SO}_{2}$ ) is responsible for the excess of mortality in men living in the more polluted area, since the levels of both pollutants were strongly correlated.

Among confounding factors only exposure to various occupational hazards appeared to be significantly related to mortality in men and women. All three types of hazards (dust, variable temperature, and high humidity) have been strongly intercorrelated, so it was impossible to distinguish the specific effect of one of them. In general, their presence probably describes burdensome conditions at work. In contrast, mortality is not related to exposure to chemicals and irritating gases at work. Perhaps this may be due to the selection of healthier workers and to some preventive measures taken when severe hazards are known to be present. Similar selection may be related in part to the somewhat lower mortality in the industrial employees than in other workers. Such effect of selection of workers has been noticed also in other studies. ${ }^{15}$

The relation of socioeconomic conditions to mortality has also been observed. ${ }^{16-18}$ In our analysis these factors have been represented by the type of occupation, dwelling conditions, and the level of education. Only the latter variable is clearly related to mortality in Cracow and only in women.

We could not draw any definite conclusions concerning the relation between mortality and the place of birth, nor its influence on the relation between mortality and air pollution. These problems need further study in a larger sample or in a sample observed for a longer time.

As the final result of the analysis we may state that the raised mortality observed in men living in the more polluted part of Cracow, which is especially pronounced in smokers, is additional to the effects of smoking habit, social conditions, or occupational factors. The real effect of air pollution may be even stronger than that observed in the study, since the residents of the higher polluted area could spend part of the day in the less polluted one and vice versa.

It is difficult to explain the inverse relation observed in women, despite the smaller reaction of women to smoking. The question is: Are the above 
observations the result of influence of some uncontrolled factors, changing the real relationship between air pollution and mortality in women, or do they reflect the smaller susceptibility of women to this type of environmental factor. To answer these questions further studies are necessary, carried out in other populations of men and women.

We thank Professor Daniel H Freeman, Jr, for his helpful suggestions and comments during the data analysis and a reviewer for his suggestions.

This research was performed in part under the scope of the agreement on joint scientific and research co-operation of the National Institute of Hygiene, Warsaw, and the National Center for Health Statistics, US DHHS.

\section{References}

${ }^{1}$ Holland WW, Bennett AE, Cameron IR, et al. Health effects of particulate pollution: reappraising the evidence. Am J Epidemiol 1979; 110: 527-659.

${ }^{2}$ Shy CM. Epidemiological evidence and the United States air quality standards. Am J Epidemiol 1979; 110: 661-71.

${ }^{3}$ Surgeon General. Smoking and health. Rockville, Md: DHEW, 1979. (DHEW Publ No/PHS/79-50066.)

${ }^{4}$ Leclerc A, Aiach P, Philippe A, Vennin M, Cebe D. Morbidité, mortalité et classe sociale. Revue bibliographique portant sur divers aspects de la patologie et discussion. Rev Epidemiol Sante Publique 1979; 27: 331-58.
${ }^{5}$ Stockwell EG, Wicks JW, Adamchak DJ. Research needed on socioeconomic differentials in US mortality. Public Health Rep 1978; 93: 666-72.

${ }^{-}$Sawicki F. Chronic nonspecific respiratory diseases in Cracow. Epidemiological Review 1972; 26: 229-50.

${ }^{7}$ Grizzle JE, Starmer CF, Koch GG. Analysis of categorical data by linear models. Biometrics 1969; 25: 489-504.

${ }^{8}$ Armitage P. Statistical methods in medical research. Oxford: Blackwell, 1971.

${ }^{9}$ Chinn S, Florey C, Baldwin IG, Gorgal M. The relation of mortality in England and Wales in 1969-73 to measurements of air pollution.J Epidemiol Community Health 1981; 35: 174-9.

${ }^{10}$ Gibbons DI, McDonald GC. Examining regression relationships between air pollution and mortality. Warren, Michigan: General Motors, 1980. (Research Publ GMR-3278.)

${ }^{11}$ Lipfert FW. Sulphur oxides, particulates and human mortality. Synopsis of statistical correlations. J Air Pollut Control Assoc 1980; 30: 366-71.

${ }^{12}$ Morris SSC, Shapiro MS, Waller JH. Adult mortality in two communities with widely different air pollution levels. Arch Environ Health 1976; 31: 248-54.

${ }^{13}$ Brozzo SR, Novak KM, Galdos F, Hakoopian R, Hamilton LD. Mortality, migration, income and air pollution: a comparative study. Soc Sci Med 1979; 13D: 95-109.

${ }^{14}$ Surgeon General. The health consequences of smoking for women. Rockville, Md: US DHHS, 1980.

${ }^{15}$ Fox AJ, Collier PI. Low mortality values in industrial cohort studies due to selection for work and survival in the industry, Br J Prev Soc Med 1976; 30: 225-30.

${ }^{16}$ Comstock GW, Tonascia JA. Education and mortality in Washington County, Md. J Health Soc Behav 1977; 18: 54-61.

${ }^{17}$ Holme I, Helgeland A, Hjermann I, Leren P, Lund-Larsen PG. Four-year mortality. by some socioeconomic indicators: the Oslo study. $J$ Epidemiol Community Health 1980; 34: 48-52.

${ }^{18}$ Näyhä S. Social group and mortality in Finland. Br J Prev Soc Med 1977; 31: 231-7. 